\title{
First natural infection by Ascocotyle (Phagicola) longa Ransom (Digenea, Heterophyidae) in an avian host, Ardea cocoi Linnaeus (Aves, Ciconiiformes, Ardeidae) in Brazil
}

\author{
Luciano Antunes Barros ${ }^{1}$ \\ Vanessa Santos de Arruda ${ }^{1}$ \\ Delir Corrêa Gomes ${ }^{1,2}$ \\ Roberto Magalhães Pinto ${ }^{1,2,3}$
}

\begin{abstract}
The first case of a natural avian infection caused by the digenetic trematode Ascocotyle (Phagicola) longa Ransom, 1920 in Brazil, is reported from the ardeid bird Ardea cocoi Linnaeus, 1766. This represents a new host record and data on clinical and pathological findings are also reported.

KEY WORDS. Digenea, Ascocotyle (Phagicola) longa, parasitic infection, Ardea cocoi, birds, pathology, trematode, parasite, Brazil
\end{abstract}

Helminth infections in Ciconiiformes hosts have been reported in nature, mainly in the United States and Brazil with relevant data to avian pathology (BARROS 2001). Studies of heterophyid trematodes have shown that they have a low host specificity and can infect piscivorous birds (Ciconiiformes) and several species of mammals.

Some helminths of Ciconiiformes play an important role as pathogens to the birds and also may involve public health, since their transmission to humans occurs by means of the ingestion of either raw or poorly cooked fish (OsHIMA 1987).

\section{MATERIAL AND METHODS}

An adult female specimen of Ardea cocoi Linnaeus, 1766, was captured for treatment on the campus of the Universidade Federal Rural do Rio de Janeiro, Seropédica, Rio de Janeiro State, in 1993, and was maintained in captivity at the Instituto de Biologia of the above referred institution. The bird was kept in a closed room, given a clinical evaluation and stool examination. Supportive care consisted in the per os administration of Lactate Ringer's solution (LRS) (50 ml each $2 \mathrm{hr}$ ), sulfametoxazole and trimetropin $(0.5 \mathrm{ml}$ each $12 \mathrm{hr})$.

Twenty-four hours after capture, the animal died and was necropsied; as the result of scraping the intestinal mucosa under a stereoscope microscope, sixty-five specimens of a digenetic trematode were recovered alive in an $0.85 \% \mathrm{NaCl}$ solution,

1) Laboratório de Helmintos Parasitos de Vertebrados, Departamento de Helmintologia, Instituto Oswaldo Cruz. Avenida Brasil 4365, 21045-900 Rio de Janeiro, Rio de Janeiro, Brasil.

2) CNPq research fellows.

3) Corresponding author. E-mail: rmpinto @ioc.fiocruz.br 
compressed and fixed in cold AFA [acetic acid $(2 \mathrm{ml})+$ formaldehyde $(5 \mathrm{ml})+80^{\circ}$ GL ethanol $(93 \mathrm{ml}) / 100 \mathrm{ml}]$ and were processed for study as described elsewhere (MUNIZ-PEREIRA \& AMATO 1995). Classification of host and parasite is according to PINTO (1978) and ScHOLZ (1999), repectively. Parasites were deposited in the Helminthological Collection of the Oswaldo Cruz Institute (CHIOC).

Fragments of the small intestine were removed and immediately fixed in $10 \%$ formalin. The material was then routinely processed for paraffin embedding. Five $\mu \mathrm{m}$ thick sections were stained with hematoxylin and eosin.

The drawing was made with the aid of a camera lucida connected to a Olympus brightfield microscope. Photomicrographs were obtained using a Zeiss brightfield microscope. Measurements are in micrometers $(\mu \mathrm{m})$, unless otherwise indicated

\section{RESULTS}

The specimen of Ardea cocoi showed signs of severe ataxia, with no reaction to capture by hands. Under inspection, a severe undernourishment was also observed, with a reduction of the muscular mass of the sternum. Gross examination of feces, showed reduction in consistency and change in color, due to the presence of digested blood, indicating lesions in the initial and/or middle portions of the gastrointestinal tract. After sedimentation of the feces, unindentified trematode eggs were detected.

During post-mortem examination, hemorrhagic enteritis, with an increase in mucus production and ulcerative lesions in the gastric and intestinal mucosae, were observed.

Histopathological examination of the intestinal mucosa revealed a discrete erosive parasitary action, causing the rupture of the small vessels, greatly promoting the occurrence of secondary infections by the trematode (Figs 2,3).

\section{Ascocotyle (Phagicola) longa Ransom, 1920}

Figs 1-3

Main morphometric data are based on two adult specimens.

Body pyriform, with spinose tegument, 378-448 long, 196-224 wide. Oral sucker 36-43 long, 43-47 wide. Anterior extremity bearing crown armed with 16 spines. Oral appendix 72 long. Pre-pharynx 50-65 long, 7 wide. Pharynx 28-36 long, 25-39 wide. Acetabulum 25-28 in diameter. Genital pore in the pre-acetabular area, posterior to the cecal bifurcation. Ovary pre-testicular, 36 long, 43 wide. Vitellaria follicular, longitudinal, in the latero-posterior region, between the ovary and the testes. Uterus in the acetabular-testicular area; uterine seminal receptacle in the middle of the ovarian-testicular area. Testes symmetrical, in the posterior third of the body. Right testis 36-61 long, 43-54 wide. Left testis 36-86 long, 54 wide. Distance of testes from posterior extremity 28-49. Eggs 18 long, 7 wide.

Host. Ardea cocoi Linnaeus, 1766; common names: white-necked heron, "socoí, maguarí, baguarí, socó grande". 


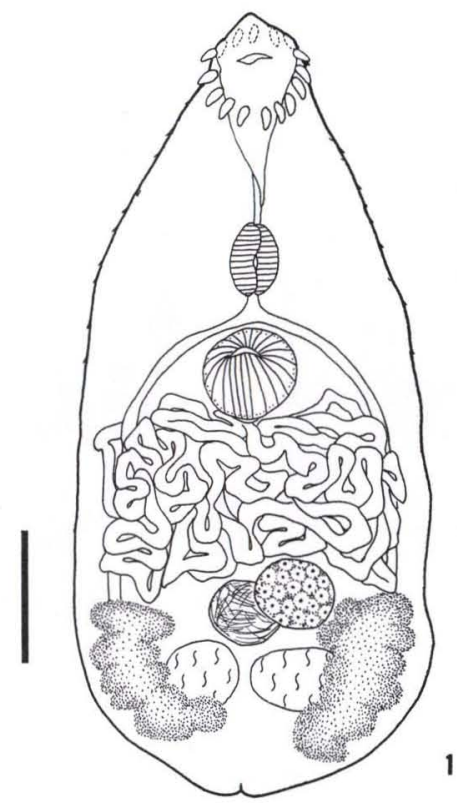

Fig. 1. Ascocotyle (Phagicola) longa, total, ventral view (Bar $=0.1 \mathrm{~mm})$.

Site of infection. Small intestine.

Locality. Seropédica, Rio de Janeiro State, Brazil.

Deposited specimens. CHIOC no. 34522 a-b (whole mounts).

Remarks. Ascocotyle (Phagicola) longa is included in the family Heterophyidae Odhner, 1914 and Mugilidae fishes (mullets) act as intermediate hosts. Adult forms of the parasite are found in the small intestine of the definitive host.

The proposal of Ascocotyle (Phagicola) longa formerly described as Ascocotyle longa by RANSOM (1920), was based on a sample recovered from the Alaskan fox Alopex lagopus (Linnaeus, 1758) that was maintained, died and was necropsied for helminths at the Washington Zoological Park, Washington, D.C., USA, in 1906.

Successful experimental infections with $A$. (P.) longa in cats, dogs and hamsters (BARROS \& AMATO 1995a, b, 1996) although indicating the low specificity of the parasite, demonstrated its capacity for inducing chronic enteritis in the different hosts.

In spite of the fact that Ascocotyle spp. are of quite common occurrence in mammals from other countries (MANFREDI \& ONETO 1997), possibly because they are more often examined for helminths, piscivorous birds are, in fact, the natural hosts that maintain the parasite life-cycle. Such birds are seldom evaluated as to their helminth fauna. Moreover, owing to the minute size of the specimens of $A$. (P.) longa they might be readly overlooked in routine parasitological examination. 

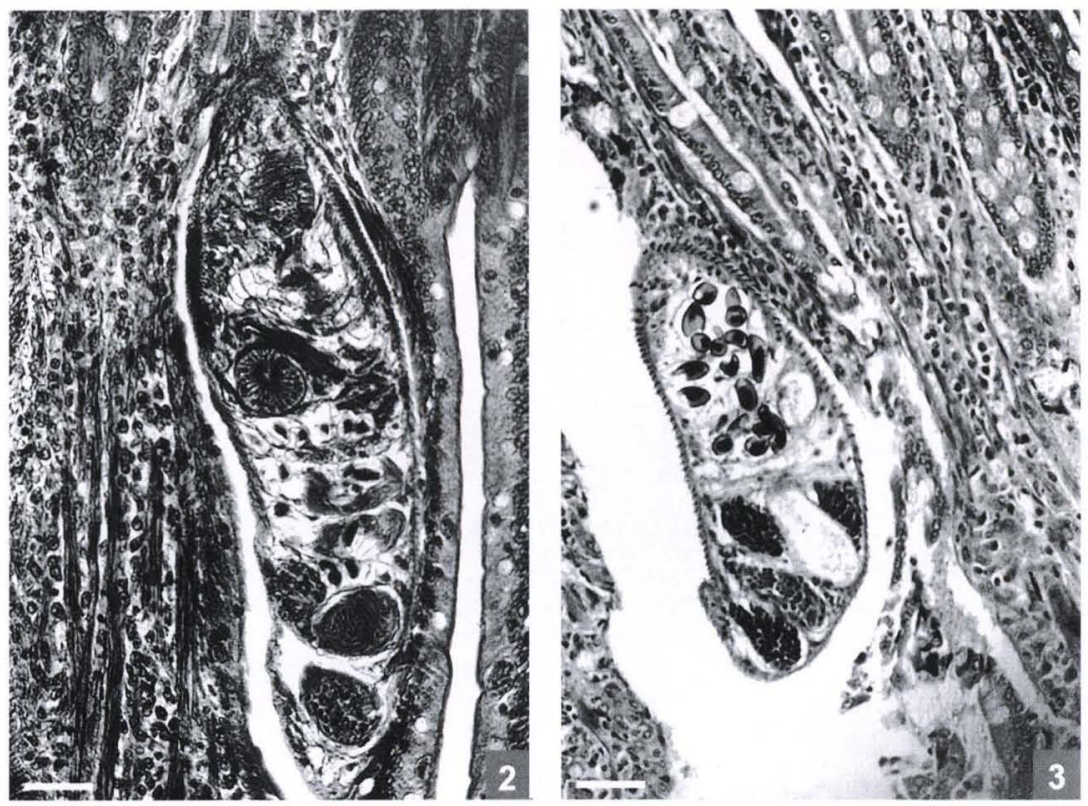

Figs 2-3. Ascocotyle (Phagicola) longa. (2) Longitudinal section of the small intestine (jejunum) of Ardea cocoi naturally infected, showing a specimen compressing the intestinal epitelium, with a discrete leucocitary infiltrate surrounding the parasite (Bar $=0.05 \mathrm{~mm}$ ); (3) longitudinal section of the small intestine (jejunum) of Ardea cocoi naturally infected, showing erosion of the mucosa and a leucocitary infiltrate surrounding the parasite $(B a r=0.05 \mathrm{~mm})$.

CHIEFFI et al. (1990, 1992), suggested that human infections with Phagicola sp. occurring in the municipalities of Cananéia and Registro in São Paulo State, Brazil, might be caused by Phagicola longa (= Ascocotyle (Phagicola) longa). These patients reportedly ate to have eaten raw mullet (Mugil sp.) as part of a Japanese diet. However, the agent of the infection was not specifically identified and generic diagnosis was obtained by the examination of eggs in the feces.

The only data on natural infections with $A$. (P.) longa in avian hosts are from the USA, related to the bald eagle Haliaeetus leucocephalus (Linnaeus, 1766) (KOCAN 1974), the spoonbill Ajaia ajaja (Linnaeus, 1758) (SEPULVEDA et al. 1994), the brown pelican Pelecanus occidentalis (Linnaeus, 1776) and the white heron Casmerodius albus (Linnaeus, 1758) (HUTTON \& SOGANDARES-BERNAL 1960).

In Brazil, there is no reference to natural infections with $A$. (P.) longa in birds. This is the first report of such occurrence and Ardea cocoi is also a new host record for the species.

ACKNOWLEDGMENTS. To Dr. Anibal Coutinho de Lemos, DVM, for the help with the treatment and necropsy of the host; to Romney Lima, Laboratório de Produção e Processamento de Imagens/ Oswaldo Cruz Institute (IOC), for technical photographic support. 


\section{REFERENCES}

BARRos, L.A. 2001. Parasites and parasitic diseases of South American Ciconiiformes, p. 87-94. In: M.E. FOWLER \& Z.S. CUBAS (Eds). Biology, medicine and surgery of South American wild animals. Iowa, Iowa State Univ. Press, 536p.

Barros, L.A. \& S.B. Аmato. 1995a. Infecções experimentais em gatos (Felis domestica) com metacercárias de Phagicola longus. Rev. Univ. Rural, Sér. Ciênc. da Vida, Seropédica, 17 (2): 49-54.

- 1995b. Aspectos patológicos observados em hamsters (Mesocricetus auritus) infectados experimentalmente com metacercárias de Phagicola longus (Ranson, 1920) Price, 1932 (Digenea, Heterophyidae). Rev. Brasil. Parasitol. Vet. 4 (1): 43-48.

- 1996. Infecções experimentais de cães com metacercárias de Phagicola longus (Ranson, 1920) Price, 1932. Rev. Brasil. Parasitol. Vet. 5 (2): 61-64.

ChiefFi, P.P.; M.C.O. Gorla; D.M.A.G.V. Torres; R.M.D.S. Dias; A.C. Mangini; A.V. Monteiro \& E. Woiciechovski. 1992. Human infection by Phagicola sp. (Trematoda, Heterophyidae) in the municipality of Registro, São Paulo State, Brazil. Jour. Trop. Med. Hyg. 95: 346-348.

Chieffi, P.P.; O.H. Leite; R.M.D. Souza-Dias; D.M.A.V. Torres \& A.C.S. Mangini. 1990. Human parasitism by Phagicola sp (Trematoda, Heterophyidae) in Cananéia, São Paulo State, Brazil. Rev. Inst. Med. Trop. São Paulo 32: 285-288.

Hutton, R.F. \& F. SOGANDARES-BERnAL. 1960. A list of parasites from marine and coastal animals of Florida, Trans. Amer. Microsc. Soc. 79: 287-292.

KoCAN, A.A. 1974. Some helminth parasites of the American bald eagle. Jour. Wildl. Dis. 10: 8-10.

MANFREDI, M.T.; M. ONETo. 1997. Phagicola longa (Heterophyidae) in dogs from Chile: morphological findings and taxonomical problems. Parasitologia 39: 9-11.

Muniz-Pereira, L.C. \& S. Amato. 1995. Natural hosts of Notocotylus breviserialis (Digenea, Notocotylidae) parasite of Brazilian waterfowl. Mem. Inst. Oswaldo Cruz 90: 711-714.

Oshima, T. 1987. Anisakiasis - is the sushi bar guilty? Parasitol. Today 3: 44-48.

PINTo, O.M.O. 1978. Novo catálogo das aves do Brasil. 1. São Paulo, Imprensa Gráfica da Revista dos Tribunais, 446p.

RANSON, B.H. 1920. Synopsis of the trematode family Heterophyidae with descriptions of a new genus and five new species. Proc. Nat. Mus. 57: 527-73.

Sepulveda, M.S.; M.G. Spalding; J.M. Kinsella; R.D. BJork \& G.S. McLaughlin. 1994. Helminths of the roseate spoonbill Ajaia ajaja in Southern Florida. Jour. Helminthol. Soc.Wash. 61: 179-189.

Scholz, T. 1999. Taxonomic study of Ascocotyle (Phagicola) longa Ransom, 1920 (Digenea: Heterophyidae) and related taxa. Syst. Parasitol. 43: 147-158.

Recebido em 20.VII.2001; aceito em 14.II.2002. 